\title{
Update: Ongoing Zika Virus Transmission - Puerto Rico, November 1, 2015-July 7, 2016
}

\begin{abstract}
Laura Adams, DVM ${ }^{1}$; Melissa Bello-Pagan, $\mathrm{MS}^{2}$; Matthew Lozier, $\mathrm{PhD}^{1}$; Kyle R. Ryff, $\mathrm{MPH}^{2}$; Carla Espinet, $\mathrm{MPH}^{2}$; Jomil Torres, $\mathrm{MS}^{2}$; Janice Perez-Padilla, $\mathrm{MPH}^{1}$; Mitchelle Flores Febo, MS ${ }^{1,2}$; Emilio Dirlikov, PhD²,3; Alma Martinez, MPH4 ; Jorge Munoz-Jordan, PhD ${ }^{1}$; Myriam Garcia ${ }^{5,6}$; Marangely Olivero Segarra, MS 5,6; Graciela Malave5,6; Aidsa Rivera, ${ }^{5} S^{1}$; Carrie Shapiro-Mendoza, PhD ${ }^{7}$; Asher Rosinger, PhD ${ }^{3,8}$; Matthew J. Kuehnert, MD ${ }^{9}$; Koo-Whang Chung, MPH ${ }^{9}$; Lisa L. Pate, $\mathrm{MD}^{10}$; Angela Harris, $\mathrm{PhD}^{1}$; Ryan R. Hemme, PhD ${ }^{1}$; Audrey Lenhart, PhD ${ }^{11}$; Gustavo Aquino, MPH ${ }^{12}$; Sherif Zaki, MD ${ }^{13}$; Jennifer S. Read, MD ${ }^{1}$; Stephen H. Waterman, MD ${ }^{1}$; Luisa I. Alvarado, MD ${ }^{14}$;

Francisco Alvarado-Ramy, MD ${ }^{15}$; Miguel Valencia-Prado, $\mathrm{MD}^{4}$; Dana Thomas, MD ${ }^{2,16}$; Tyler M. Sharp, PhD ${ }^{1}$; Brenda Rivera-Garcia, DVM ${ }^{2}$
\end{abstract}

\section{On July 29, 2016, this report was posted as an MMWR Early Release on the MMWR website (http://www.cdc.gov/mmwr).}

Zika virus is a flavivirus transmitted primarily by Aedes aegypti and Aedes albopictus mosquitoes, and infection can be asymptomatic or result in an acute febrile illness with rash (1). Zika virus infection during pregnancy is a cause of microcephaly and other severe birth defects (2). Infection has also been associated with Guillain-Barré syndrome (GBS) (3) and severe thrombocytopenia $(4,5)$. In December 2015, the Puerto Rico Department of Health (PRDH) reported the first locally acquired case of Zika virus infection. This report provides an update to the epidemiology of and public health response to ongoing Zika virus transmission in Puerto Rico $(6,7)$. A confirmed case of Zika virus infection is defined as a positive result for Zika virus testing by reverse transcriptionpolymerase chain reaction (RT-PCR) for Zika virus in a blood or urine specimen. A presumptive case is defined as a positive result by Zika virus immunoglobulin $\mathrm{M}$ (IgM) enzyme-linked immunosorbent assay (MAC-ELISA)* and a negative result by dengue virus IgM ELISA, or a positive test result by Zika IgM MAC-ELISA in a pregnant woman. An unspecified flavivirus case is defined as positive or equivocal results for both Zika and dengue virus by IgM ELISA. During November 1, 2015-July 7, 2016, a total of 23,487 persons were evaluated by PRDH and CDC Dengue Branch for Zika virus infection, including asymptomatic pregnant women and persons with signs or symptoms consistent with Zika virus disease or suspected GBS; 5,582 (24\%) confirmed and presumptive Zika virus cases were identified. Persons with Zika virus infection were residents of 77 (99\%) of Puerto Rico's 78 municipalities. During 2016, the percentage of positive Zika virus infection cases among symptomatic males and nonpregnant females who were tested increased from 14\% in February to 64\% in June. Among 9,343 pregnant women tested, 672 had confirmed or presumptive Zika virus infection, including 441 (66\%) symptomatic women and $231(34 \%)$ asymptomatic women. One patient died after developing severe thrombocytopenia

*CDC Zika MAC-ELISA (http://www.fda.gov/downloads/MedicalDevices/ Safety/EmergencySituations/UCM488044.pdf).
(4). Evidence of Zika virus infection or recent unspecified flavivirus infection was detected in 21 patients with confirmed GBS. The widespread outbreak and accelerating increase in the number of cases in Puerto Rico warrants intensified vector control and personal protective behaviors to prevent new infections, particularly among pregnant women.

\section{Epidemiologic Surveillance}

Epidemiologic surveillance for Zika virus in Puerto Rico has previously been described, and includes testing of all symptomatic persons for evidence of Zika, dengue, or chikungunya virus infection using the Trioplex RT-PCR ${ }^{\dagger}$ or MAC-ELISA tests (7). During November 1, 2015-July 7, 2016, specimens from 16,522 symptomatic patients with suspected arboviral disease were evaluated. A total of 5,106 (31\%) confirmed and 245 (1\%) presumptive Zika virus infections were identified. In addition, test results for $136(<1 \%)$ patients were positive for recent dengue virus infection, results for $127(<1 \%)$ were positive for recent unspecified flavivirus infection, and results for $100(<1 \%)$ were positive for recent chikungunya virus infection. Among the 5,351 symptomatic patients with evidence of recent Zika virus infection, 441 (8\%) were pregnant women (Table 1). Thirty-six confirmed or suspected cases of GBS (8) were reported to PRDH by providers throughout the island. Among these patients, 21 (61\%) had evidence of Zika virus or flavivirus infection, including five (14\%) with confirmed and $11(33 \%)$ with presumptive Zika virus infections, and five $(14 \%)$ with unspecified flavivirus infections. Sixty-five $(<1 \%)$ of 5,131 symptomatic patients with confirmed or presumptive Zika virus infection required hospitalization, including all GBS patients. One male patient with Zika virus infection died of complications related to severe thrombocytopenia (4). Sixty-five infants were born to women with evidence of Zika virus infection in pregnancy, and two pregnancy losses were identified. In one pregnancy loss, Zika virus was identified in neural tissue by immunohistochemistry. No cases of congenital Zika virus infection among live births in Puerto Rico have been

\footnotetext{
$\dagger$ Trioplex RT-PCR test (http://www.fda.gov/downloads/MedicalDevices/Safety/ EmergencySituations/UCM491592.pdf).
} 
identified. All pregnant women with confirmed or presumptive Zika virus infection, or unspecified flavivirus infection, and their prenatally exposed offspring are being actively monitored for adverse maternal, fetal, neonatal, infant, and child health outcomes through the Zika Active Pregnancy Surveillance System, ${ }^{\S}$ a collaboration between PRDH and CDC. PRDH has followed CDC recommendations that pregnant women in areas with evidence of active Zika virus transmission receive screening tests during the first and second trimesters of pregnancy, regardless of symptoms (9). Among 7,308 asymptomatic pregnant women tested during January-July 2016, $43(<1 \%)$ confirmed and 188 (3\%) presumptive Zika virus infections were identified. The percentage of asymptomatic pregnant women with confirmed or presumptive recent Zika virus infection among women tested increased almost sixfold, from $0.8 \%$ in February 2016 to $5.3 \%$ in June 2016.

The number of Zika virus infections reported each week in Puerto Rico gradually increased during November 2015February 2016, and remained relatively stable until April 2016 (Figure 1). The number of persons with recent Zika virus infection reported each week began to increase in April 2016, and steadily increased through June. Overall, Puerto Rico reported 291 new confirmed and presumptive Zika virus cases during February 2016; 2,612 new confirmed and presumptive Zika virus cases were reported during June, a nearly eightfold increase. Among symptomatic males and nonpregnant females who were tested, the percentage of persons with confirmed or presumptive Zika virus infection increased threefold from $14 \%$ in February to $64 \%$ in June; during the same time, the percentage of persons with confirmed or presumptive Zika virus infection among symptomatic pregnant women increased fivefold, from $8 \%$ to $41 \%$.

Suspected cases of Zika virus disease were reported in all 78 municipalities, and Zika virus-infected patients were residents of 77 (99\%) municipalities (Figure 2). The more populous municipalities of San Juan and Ponce reported the highest numbers of confirmed and presumptive Zika virus cases, with fewer cases occurring in the rural municipalities of Puerto Rico.

On April 3, 2016, local collection of blood donation specimens resumed (the Food and Drug Administration had recommended cessation of blood collection in areas of the United States affected by active vectorborne transmission of Zika virus and importation of all blood components from the continental United States beginning March 59). Zika virus screening using a nucleic acid test (cobas Zika, Roche Molecular Systems, Inc., Pleasanton, California) was

\footnotetext{
$\$$ Zika Active Pregnancy Surveillance System is co-operated by PRDH and CDC. Thttp://www.fda.gov/downloads/BiologicsBloodVaccines/ GuidanceComplianceRegulatoryInformation/Guidances/Blood/UCM486360.pdf.
}

TABLE 1. Pregnant women with test results positive for Zika virus infection - Puerto Rico, November 1, 2015-July 7, 2016

\begin{tabular}{lccc}
\hline Clinical status & $\begin{array}{c}\text { Confirmed } \\
\text { positive* }^{*}\end{array}$ & $\begin{array}{c}\text { Presumptive } \\
\text { positive }^{\dagger}\end{array}$ & Total tested \\
\hline Symptomatic & 383 & 58 & 2,035 \\
Asymptomatic & 43 & 188 & 7,308 \\
Total & 426 & 246 & 9,343 \\
\hline
\end{tabular}

* A confirmed case was defined as a positive result for Zika virus by reverse transcription-polymerase chain reaction testing.

${ }^{\dagger} \mathrm{A}$ presumptive case was defined as a positive result by Zika virus immunoglobulin $\mathrm{M}$ enzyme-linked immunosorbent assay.

authorized by the Food and Drug Administration under an investigational new drug application (10). A blood donation specimen with an initial reactive result by nucleic acid testing is regarded as presumptive positive for Zika virus infection. During the weeks of April 3 through July 3, among 18,163 donation specimens tested, $143(0.8 \%)$ were identified as presumptive positive for Zika virus. The percentage of blood donation specimens testing positive by week has increased, with the highest percentage (1.8\%) occurring during the latest week of reporting (week beginning July 3) (Figure 3).

\section{Public Health Response}

$\mathrm{PRDH}$, in collaboration with CDC, implemented a Zika virus response strategy with three focus areas: protecting pregnant women, controlling the mosquito vector, and expanding access to the full range of voluntary contraceptive options for women and men. Health messaging, such as television and radio public service announcements, has been implemented, health education materials have been distributed at locations, including health care facilities and community events, and weekly arboviral surveillance reports with island-wide and municipal-level information have been posted online. ${ }^{* *, \dagger \dagger}$ Outreach to travelers has included health messaging via television screens and flyers at ports of entry, hotels, and tourist places of interest as well as training airport and tourism personnel. Community intervention strategies have focused on pregnant women. PRDH has worked closely with Women, Infants, and Children (WIC) clinics, where $90 \%$ of pregnant women residing in Puerto Rico received services in 2015 (Dana Miró Medina, LND, WIC Puerto Rico, personal communication, 2016), to provide approximately 12,900 Zika prevention kits to pregnant women; the kits include insect repellent, bed nets, condoms, and larvicide to prevent mosquito breeding sites in water-holding containers around households. Since February 2016, approximately 21,000 pregnant women, representing

\footnotetext{
** http://www.salud.gov.pr/Estadisticas-Registros-y-Publicaciones/Informes\%20 Arbovirales/Forms/AllItems.aspx.

${ }^{\dagger \dagger}$ http://www.salud.gov.pr/Estadisticas-Registros-y-Publicaciones/Pages/ Reporte-de-Zika-por-Municipios.aspx.
} 
FIGURE 1. Cases of confirmed and presumptive Zika virus infection $(\mathrm{N}=5,582)$, by pregnancy status and week of illness onset or specimen collection, and percentage of persons with test results positive for Zika virus — Puerto Rico, November 1, 2015-July 7, 2016*

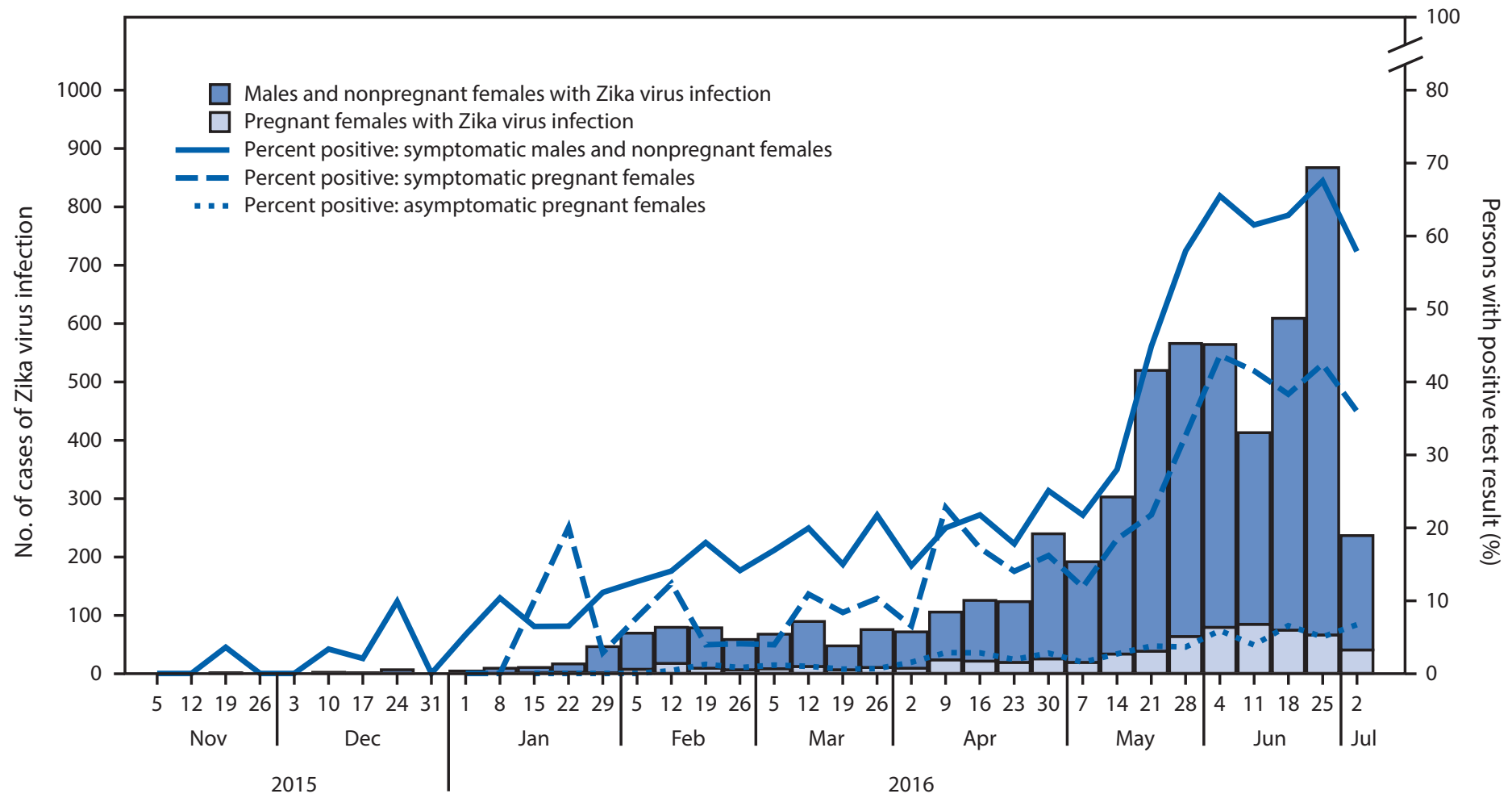

Week of illness onset/specimen collection

* The decrease in cases for the first week of July 2016 might reflect a reporting delay.

FIGURE 2. Municipality of residence of persons with confirmed and presumptive Zika virus infection $(n=4,986)-$ Puerto Rico, November 1 , 2015-July 7, 2016*

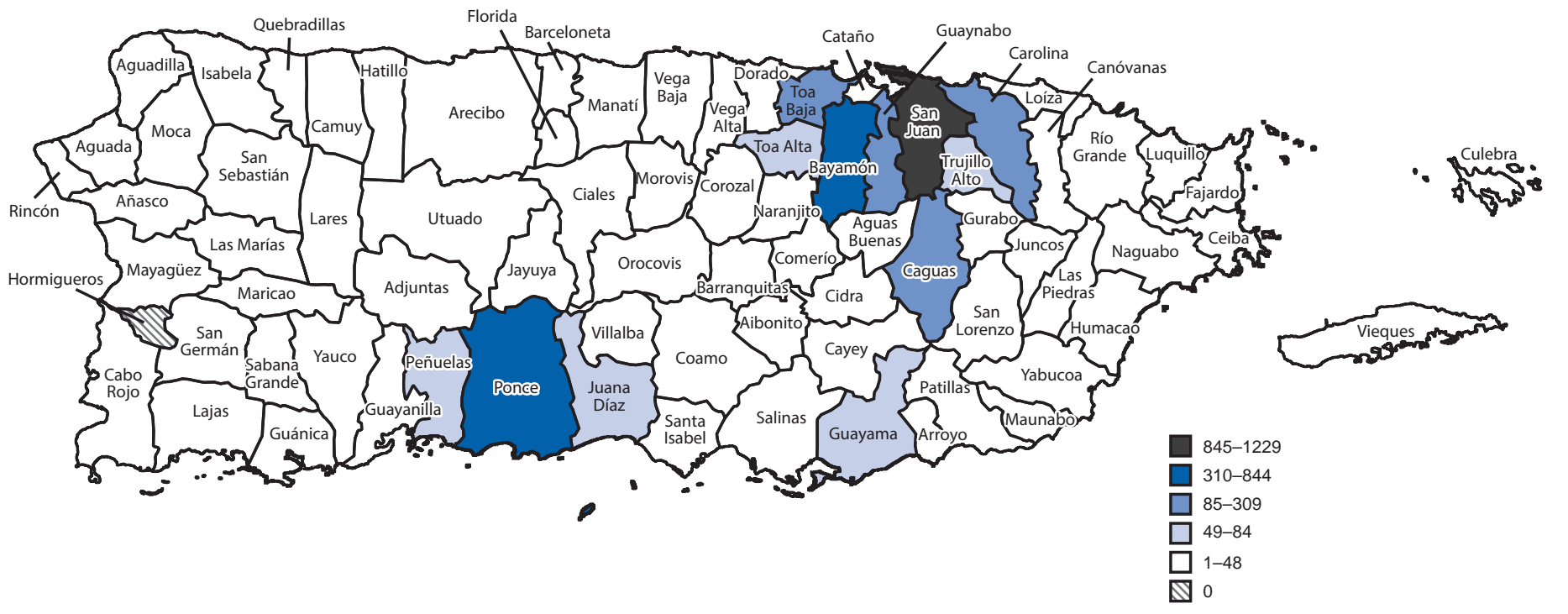

* 596 additional cases were reported in persons with unknown municipality of residence. 
FIGURE 3. Percentage of screened blood donations reactive for Zika virus infection, by week of testing - Puerto Rico, April 3-July 3, 2016

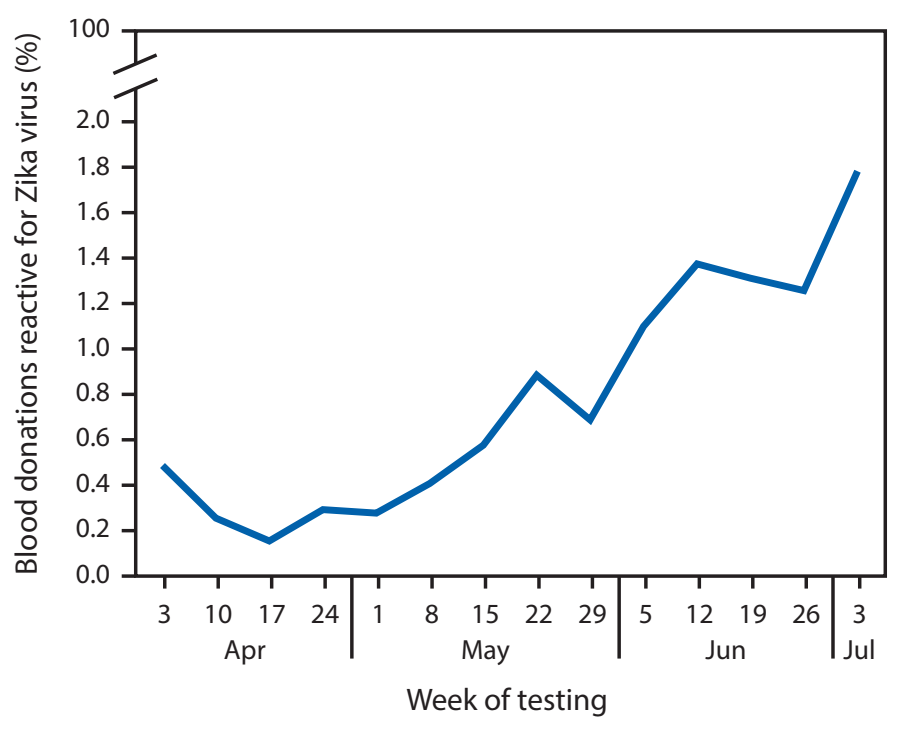

approximately $67 \%$ of the estimated number of pregnant women per year based on 2015 birth rates, have been counseled about Zika virus prevention at WIC clinics. In addition, to reduce the risk for unintended pregnancies, the public health response includes community outreach and education about sexual transmission of Zika virus, distribution of male and female condoms, and an increase in the availability of the full range of voluntary contraceptive methods, including longacting reversible contraceptives (11). PRDH and CDC have also implemented a representative, population-based survey of women aged 18-49 years to assess contraception use through the Behavioral Risk Factor Surveillance System.

Pregnant women across the island identified through WIC are offered vector control services carried out by a contracted pest control company; these services include source reduction of mosquito breeding sites, larvicide application, and residual indoor and outdoor insecticide spraying with deltamethrin. The Puerto Rico Public Housing Administration has led programs to incorporate residual insecticide spraying with deltamethrin and, in collaboration with Puerto Rico Department of Family Affairs, is working to install screens in the homes of pregnant women.

During February-March 2016, a CDC laboratory in Puerto Rico conducted an insecticide resistance study of Ae. aegypti mosquitoes to guide vector control strategies. Mosquitoes from across Puerto Rico were tested using the CDC bottle bioassay (12). Results from the laboratory study indicated widespread resistance to pyrethroids throughout the island with the exception of partial resistance to deltamethrin and full susceptibility to naled, an organophosphate insecticide. Insecticide resistance surveillance is ongoing in the CDC laboratory. Use of lethal adult mosquito traps, which have previously been associated with reduced $A$ e. aegypti numbers and incidence of arboviral infections in Puerto Rico, is also under consideration $(13,14)$.

$\mathrm{PRDH}$ and CDC have collaborated to ensure that all public schools are sprayed with deltamethrin before the school year starts in early August. Furthermore, PRDH and the Puerto Rico Emergency Management Agency have collaborated with municipalities to initiate community cleanup campaigns using larvicide to prevent mosquito breeding in water-holding containers around households and to remove mosquito breeding sites, such as trash heaps and septic tanks. In addition, the Puerto Rico Emergency Management Agency and the Puerto Rico Environmental Quality Board have removed approximately 1.6 million rubber tires that could act as mosquito breeding sites.

Women with evidence of Zika virus infection during pregnancy and their exposed offspring are monitored for adverse maternal, fetal, neonatal, infant, and child health outcomes through the Zika Active Pregnancy Surveillance System. Puerto Rico's Birth Defects Surveillance and Prevention System, in collaboration with maternal fetal medicine specialists, monitors the ultrasound findings of pregnant women infected with Zika virus. Beginning in January 2016, the Birth Defects Surveillance and Prevention System began identifying newborns with congenital microcephaly, including those born to women infected with Zika virus during pregnancy. All newborns of women with evidence of Zika virus infection during pregnancy are referred to the Children with Special Health Care Needs program for developmental surveillance and coordinated specialized services, for up to age 3 years as needed. All newborns with congenital microcephaly will be referred to Avanzando Juntos, Puerto Rico's early intervention services system.

\section{Discussion}

Both the number of Zika virus infections and percentage of tests among symptomatic persons and asymptomatic pregnant women that are positive are rapidly increasing in Puerto Rico. In addition, unspecified flavivirus cases, while indistinguishable by available laboratory tests, are likely attributable to Zika virus infection, as Zika virus is the predominant circulating flavivirus; Zika virus was identified in 5,351 suspected arboviral cases, compared with 136 dengue cases. Many persons with symptomatic Zika virus infection do not seek medical care or are not reported to public health officials, and most persons with Zika virus infection are asymptomatic (15), but can still infect mosquitoes and might unknowingly transmit the virus through sexual contact (16), blood donation (10), or vertically, to the fetus (17). The prevalence of Zika virus infection in Puerto Rico is substantial and increasing, with the most recent data indicating that $5 \%$ of asymptomatic pregnant women and $1.8 \%$ of blood donations 


\section{Summary}

What is already known about this topic?

Zika virus transmission in Puerto Rico has been increasing since it was first detected in November 2015. Zika virus infection is a cause of microcephaly and other severe birth defects and has been associated with Guillain-Barré syndrome and severe thrombocytopenia.

What is added by this report?

During November 1, 2015-July 7, 2016, specimens from 16,522 patients with suspected Zika virus disease in Puerto Rico were evaluated and 5,351 (32\%) had laboratory evidence of current or recent Zika virus infection. The percentage of persons with confirmed or presumptive Zika virus infection among symptomatic pregnant females increased from $8 \%$ in February 2016 to $41 \%$ in June 2016 ; during the same time, the percentage of persons with confirmed or presumptive Zika virus infection among symptomatic males and nonpregnant females increased from $14 \%$ to $64 \%$. The public health response includes increased surveillance for Zika virus infection, preventing infection in pregnant women, monitoring infected pregnant women and their fetuses for adverse outcomes, controlling mosquitoes, assuring the safety of blood products, and expanding access to the full range of voluntary contraceptive options for women and men.

What are the implications for public health practice?

The Zika virus outbreak in Puerto Rico continues to expand in geographic extent and number of infected persons. Residents of and travelers to Puerto Rico should continue to employ mosquito bite avoidance behaviors, take precautions to reduce the risk for sexual transmission, and seek medical care for any acute illness with rash or fever. Intensified vector control measures, including an integrated vector management strategy, are needed to help reduce disease spread. Clinicians who suspect Zika virus disease in patients who reside in or have recently returned from areas with ongoing Zika virus transmission should consider testing for Zika virus and report cases to public health officials.

have evidence of recent infection in the most recent reported week of screening (week beginning July 3) (10).

Since the introduction of Zika virus to Puerto Rico in late 2015, the virus has spread to nearly all municipalities. The pattern of spread in Puerto Rico is consistent with that of newly introduced arboviruses into an immunologically naive population: transmission began in the heavily populated eastern region and subsequently spread to the southern and western parts of the island, with lower infection rates in the central mountainous regions $(18,19)$. Arboviral outbreaks in Puerto Rico tend to peak in the late summer and fall, coincident with hotter months with higher rainfall, raising concern that the outbreak will continue and the incidence will increase during the coming months $(18,19)$.

Patterns observed after the introduction of other arboviruses into Puerto Rico, and evidence that the Zika virus outbreak exhibits no signs of abating, underscore the critical need for rapid, intensified measures to prevent infections among pregnant women. Surveillance data indicate that during June 2016, despite current interventions, approximately 322 pregnant women received diagnoses of having been newly infected in Puerto Rico, emphasizing the need for an aggressive, integrated vector management strategy coupled with intensive counseling and care for pregnant women.

Measures to strengthen vector control in Puerto Rico include more intensive source reduction and larvicide application activities, community engagement, use of lethal adult mosquito traps, and consideration of strategies for vector control with insecticides to which local populations of Ae. aegypti are susceptible. A preliminary CDC evaluation of residual insecticide spraying indicates that adult mosquito populations in and around sprayed homes remained comparable to counts in and around unsprayed homes, probably as a result of movement of mosquitoes from nearby homes with breeding sources.

Residents of and travelers to Puerto Rico should continue to employ mosquito bite avoidance behaviors, including using mosquito repellents, wearing long-sleeved shirts and pants, and ensuring that windows and doors have screens, and air conditioning is used, to avoid bites while indoors. ${ }^{\$ \$}$ To reduce the risk for sexual transmission, especially to pregnant women, precautions should include consistent and correct use of condoms or abstinence (20). Women in Puerto Rico who do not desire pregnancy need access to effective and affordable voluntary contraception to avoid unintended pregnancies (11).99 Clinicians who suspect Zika virus disease in patients who reside in or have recently returned from areas such as Puerto Rico with ongoing Zika virus transmission should consider testing for Zika virus and report cases to public health officials.

\footnotetext{
$\$ \$$ http://www.cdc.gov/zika/prevention/.

99 http://www.cdc.gov/reproductivehealth/UnintendedPregnancy/ Contraception.htm.
}

\section{Acknowledgments}

Elba V. Caraballo, Chelsea G. Major, Division of Vector-Borne Diseases, National Center for Emerging and Zoonotic Infectious Diseases, CDC; Office for State, Tribal, Local, and Territorial Support, CDC; Marrielle Mayshack, Office for State, Tribal, Local, and Territorial Support, CDC; Susan A. Galel, Roche Molecular Systems, Inc., Pleasanton, California.

\footnotetext{
${ }^{1}$ Division of Vector-Borne Diseases, National Center for Emerging and Zoonotic Infectious Diseases, CDC; ${ }^{2}$ Office of Epidemiology and Research, Puerto Rico Department of Health; ${ }^{3}$ Epidemic Intelligence Service, Division of Scientific Education and Professional Development, CDC; ${ }^{4}$ Puerto Rico Birth Defects Surveillance and Prevention System, Puerto Rico Department of Health; ${ }^{5}$ Biological and Chemical Emergencies Laboratory, Office of Public Health Preparedness and Response, Puerto Rico Department of Health; ${ }^{6}$ Public Health Laboratory, Puerto Rico Department of Health; ${ }^{7}$ Division of Reproductive Health, National Center for Chronic Disease Prevention and Health Promotion, CDC; ${ }^{8}$ Division of Health and Nutrition Examination Surveys, National Center for Health Statistics; ${ }^{9}$ Division of Healthcare Quality Promotion, National
} 
Center for Emerging and Zoonotic Infectious Diseases, CDC; ${ }^{10}$ Roche Molecular Systems, Inc., Pleasanton, California; ${ }^{11}$ Entomology Branch, Division of Parasitic Diseases and Malaria, Center for Global Health, CDC; ${ }^{12}$ Office of the Director, National Center for HIV/AIDS, Viral Hepatitis, STD, and TB Prevention, CDC; ${ }^{13}$ Infectious Diseases Pathology Branch, Division of High-Consequence Pathogens and Pathology, National Center for Emerging and Zoonotic Infectious Diseases, CDC; ${ }^{14}$ Ponce Health Sciences UniversitySaint Luke's Episcopal Hospital Consortium, Puerto Rico; ${ }^{15}$ Division of Global Migration and Quarantine, National Center for Emerging and Zoonotic Infectious Diseases, CDC; ${ }^{16}$ Division of State and Local Readiness, Office of Public Health Preparedness and Response, CDC.

Corresponding author: Laura Adams, leadams@cdc.gov, 787-706-2249.

\section{References}

1. Petersen LR, Jamieson DJ, Powers AM, Honein MA. Zika Virus. N Engl J Med 2016;374:1552-63. http://dx.doi.org/10.1056/NEJMra1602113

2. Rasmussen SA, Jamieson DJ, Honein MA, Petersen LR. Zika virus and birth defects - reviewing the evidence for causality. N Engl J Med 2016;374:1981-7. http://dx.doi.org/10.1056/NEJMsr1604338

3. Cao-Lormeau VM, Blake A, Mons S, et al. Guillain-Barré Syndrome outbreak associated with Zika virus infection in French Polynesia: a casecontrol study. Lancet 2016;387:1531-9. http://dx.doi.org/10.1016/ S0140-6736(16)00562-6

4. Sharp TM, Muńoz-Jordán J, Perez-Padilla J, et al. Zika virus infection associated with severe thrombocytopenia. Clin Infect Dis 2016; pii:ciw476. Epub July 14, 2016. http://dx.doi.org/10.1093/cid/ciw476

5. Karimi O, Goorhuis A, Schinkel J, et al. Thrombocytopenia and subcutaneous bleedings in a patient with Zika virus infection. Lancet 2016;387:939-40. http://dx.doi.org/10.1016/S0140-6736(16)00502-X

6. Thomas DL, Sharp TM, Torres J, et al. Local transmission of Zika Virus-Puerto Rico, November 23, 2015-January 28, 2016. MMWR Morb Mortal Wkly Rep 2016;65:154-8. http://dx.doi.org/10.15585/ mmwr.mm6506e2

7. Dirlikov E, Ryff KR, Torres-Aponte J, et al. Update: ongoing Zika virus transmission-Puerto Rico, November 1, 2015-April 14, 2016. MMWR Morb Mortal Wkly Rep 2016;65:451-5. http://dx.doi.org/10.15585/ mmwr.mm6517e2

8. Sejvar JJ, Kohl KS, Gidudu J, et al. Guillain-Barré syndrome and Fisher syndrome: case definitions and guidelines for collection, analysis, and presentation of immunization safety data. Vaccine 2011;29:599-612. http://dx.doi.org/10.1016/j.vaccine.2010.06.003

9. Simeone RM, Shapiro-Mendoza CK, Meaney-Delman D, et al. Possible Zika virus infection among pregnant women-United States and territories, May 2016. MMWR Morb Mortal Wkly Rep 2016;65:514-9. http://dx.doi.org/10.15585/mmwr.mm6520e1
10. Kuehnert MJ, Basavaraju SV, Moseley RR, et al. Screening of blood donations for Zika virus infection-Puerto Rico, April 3-June 11, 2016. MMWR Morb Mortal Wkly Rep 2016;65:627-8. http://dx.doi. org/10.15585/mmwr.mm6524e2

11. Tepper NK, Goldberg HI, Bernal MI, et al. Estimating contraceptive needs and increasing access to contraception in response to the Zika virus disease outbreak-Puerto Rico, 2016. MMWR Morb Mortal Wkly Rep 2016;65:311-4. http://dx.doi.org/10.15585/mmwr.mm6512e1

12. Brogdon W, Chan A. Guidelines for evaluating insecticide resistance in vectors using the CDC bottle bioassay/methods in Anopheles research. Atlanta, GA: US Department of Health and Human Services, CDC; 2010. https://www.cdc.gov/malaria/resources/pdf/fsp/ir_manual/ ir_cdc_bioassay_en.pdf

13. Lorenzi OD, Major C, Acevedo V, et al. Reduced incidence of chikungunya virus infection in communities with ongoing Aedes aegypti mosquito trap intervention studies-Salinas and Guayama, Puerto Rico, November 2015-February 2016. MMWR Morb Mortal Wkly Rep 2016;65:479-80. http://dx.doi.org/10.15585/mmwr.mm6518e3

14. Barrera R, Amador M, Acevedo V, Caban B, Felix G, Mackay AJ. Use of the CDC autocidal gravid ovitrap to control and prevent outbreaks of Aedes aegypti (Diptera: Culicidae). J Med Entomol 2014;51:145-54. http://dx.doi.org/10.1603/ME13096

15. Duffy MR, Chen TH, Hancock WT, et al. Zika virus outbreak on Yap Island, Federated States of Micronesia. N Engl J Med 2009;360:2536-43. http://dx.doi.org/10.1056/NEJMoa0805715

16. Fréour T, Mirallié S, Hubert B, et al. Sexual transmission of Zika virus in an entirely asymptomatic couple returning from a Zika epidemic area, France, April 2016. Euro Surveill 2016;21:30254. http://dx.doi. org/10.2807/1560-7917.ES.2016.21.23.30254

17. Pacheco O, Beltrán $\mathrm{M}$, Nelson CA, et al. Zika virus disease in Colombia—preliminary report. N Engl J Med 2016;NEJMoa1604037. http://dx.doi.org/10.1056/NEJMoa1604037

18. Sharp TM, Roth NM, Torres J, et al. Chikungunya cases identified through passive surveillance and household investigations - Puerto Rico, May 5 August 12, 2014. MMWR Morb Mortal Wkly Rep 2014;63:1121-8.

19. Sharp TM, Hunsperger E, Santiago GA, et al. Virus-specific differences in rates of disease during the 2010 dengue epidemic in Puerto Rico. PLoS Negl Trop Dis 2013;7:e2159. http://dx.doi.org/10.1371/journal.pntd.0002159

20. Brooks JT, Friedman A, Kachur RE, LaFlam M, Peters PJ, Jamieson DJ. Update: interim guidance for prevention of sexual transmission of Zika virus_-United States, July 2016. MMWR Morb Mortal Wkly Rep 2016;65. Epub July 25, 2016. http://dx.doi.org/10.15585/mmwr.mm6529e2 